\title{
Chinese College Students' Competence in Spoken English: Problems and Tactics
}

\author{
Liu Dan \\ School of Public English Teaching and Research \\ Harbin Normal University \\ Harbin 150025, China \\ Email: liudan309@126.com
}

\begin{abstract}
In order to investigate the situation of college students' oral English competence in China, an oral test was carried out. Through the statistical analysis from the result of the test, some problems are found out, which are just the actuality the Chinese college students have to face about their oral English competence. Then some effective ways are discussed from two aspects: in-class tactics and after-class guidance. This study is helpful to the knowledge of China's current situation of college English teaching, and to the development of spoken English teaching and learning.
\end{abstract}

Keywords-teaching tactics; spoken English; test; competence; second language

\section{INTRODUCTION}

With the rapid development of information age, more and more people communicate in the international language-English, especially spoken English. Chinese college English teaching revolution is booming nowadays. The improvement of college students' competence in spoken English becomes a very crucial part in English teaching. At the same time, a new issue appears on how to improve students' competence in spoken English, which is the focus in college English teaching. In order to probe into the question, an oral test is carried out. College English oral test firstly began in China at the end of 20th century. The design principle is based on communication information in reality, that is, providing real scenes, creating mock communication environments and at the same time embodying communication mutuality [1]. In order to show this principle, many Chinese universities test and exercise the students' oral competence in mock communication environment.

\section{TEST ANALYSIS}

For the sake of the development of college English teaching and the improvement of the students' oral competence, we need to know the condition of the students' oral competence. Thus, a test is carried out to know the situation of college students' oral competence.

The content of the test is about common topics in daily life on campus or in society, such as in the dining hall, in the library, in the gymnasium, in the shop, in the post office, and also in online voice chat. The mode of the test is as the followings: nearly fifty hundreds of undergraduates from the advanced classes, the ordinary classes and the junior classes took part in the oral test. After the test, two hundreds stochastic data are drawn from the mass of results. The test examines their oral English competence from four aspects: content of speech, the ability of language expression, grammar correctness and English intonation, as shown in figure 1 . The weight ratio of each aspect in the test is also indicated in figure 1.

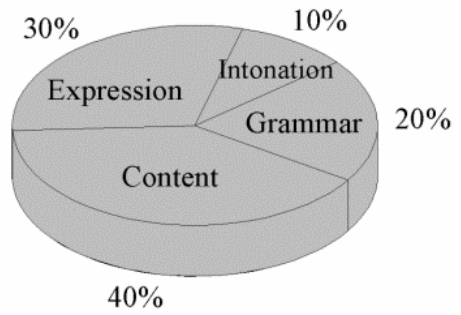

Figure 1. The criterion of the test

According to the stochastic data, we get the final grades of the students by plus of the results from the four aspects. The full mark is one hundred. Five points are regarded as one score range. Each score range corresponds to the percentage in the whole stochastic students as shown in figure 2 .

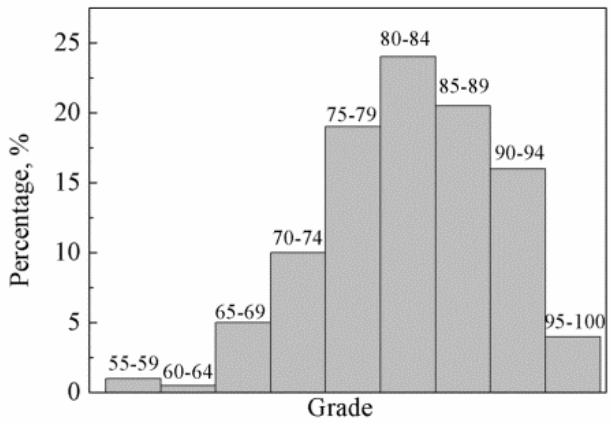

Figure 2. Percentage distribution of final grades

In figure 2, the whole trend of the test shows that the large proportion of students' oral competence is in the middle level or in the upper level, which indicates a better condition of oral competence than the old "dumb English" age in China in many years ago. Even the shyest student can say something under the encouragement. But some problems are still existing. 
For the content of spoken English, many students seem to have little to say, although they know a lot about the topic [2]. Some of the topics like dining in the hall, shopping in the mall, are often mentioned among them. If they talk about any of the topics in Chinese, there will always be a lot to say, but in a foreign language, the things become different. In the test, only about one third of the students give a comparatively abundant content in their speech.

According to the interviews to some of the students after the test, their words show that sometimes it is hard for them to choose words and phrases to express themselves, and sometimes hard for them to organize the mass of materials in the minds. That affected their grades in language expression. Besides, they tells their embarrassment when speaking in English in their college life on campus. That is, they have little chance to speak English outside of college English class on campus. If someone communicates with his or her classmates in English in the daily life, he or she will be regarded as "an odd fish" on campus, which embarrasses every student. That makes most of the Chinese students shy in English expression.

Talking about grammar, most of the Chinese students feel proud of themselves. They have learned grammar for about seven years in middle school. Although the emphasis of Chinese college English teaching has changed from grammar to communication these years, most of the Chinese students have solid ground in grammar. Before they open their mouths, the first thing into their minds is grammar. That makes them take a long time to arrange language materials into a grammatically logical sentence.

As for intonation, it takes small proportion in the oral test, but it plays an indispensable role in a speech. The rise and fall of the voice in speaking makes the speech more pleasing to the ear. Intonation can not make an effect on the conveyance of meaning in written words, but in spoken English it sometimes means something different. A sentence conveying a good meaning of praise, can have the opposite meaning if the intonation is misused. Most Chinese students are busy remembering new words, learning grammar, reading books, and going over for the written examinations, so some of them ignore the importance of intonation in a speech.

\section{TACTICS TO IMPROVE ORAL COMPETENCE}

To solve the problems reflected from the oral test, some effective tactics should be found out in this part. The paper discusses the issue from two aspects: in-class tactics and after-class guidance. In class, the teacher can employ many tactical teaching to help students practice spoken English. But the limited time in class determines that the students should take full advantage of the after-class time if they want to improve their oral competence.

\section{A. In-class Tactics}

To the question of the content of spoken English, the teacher may help students summarize some common sentences of various kinds of topics, then encourage them use these sentences. For example, the teacher gives them a supposed situation and asks them to make suited dialogues.
Or the teacher makes students give a role play before class or as a warming-up for the class. The students will feel interesting and at the same time solve the problem of the lack of oral practice in class.

According to the interviews after the test, we know that sometimes it is hard for the students to choose proper words and phrases to express themselves. So in class the teacher should provide more opportunities for the students to use new words and phrases by asking them to make sentences, or by directing some activities like identifying the appropriate words and phrases in a given topic. After that, assign a role play to them as a homework for the warmingup in the next class. The students should be encouraged to practice self-expression and learn to get used to posing questions in class.

Over seven years of grammar learning experience makes most of the students have solid ground in grammar, and at the same time limits their thought and way of speaking. Before they open their mouths, the first thing into their minds is grammar, which makes them take a long time to arrange language materials in mind into a grammatically logical sentence. When dealing with such kind of problems, the teacher can give them some short listening materials or video segments in class, then ask them to repeat the what they see or hear as much and quick as possible. At first, the students may speak little, but if the materials are interesting and attractive enough for them, they will have an urge to tell others what they see or hear. At that time, they leave what is called grammar behind at all.

As for intonation, the teacher can help students to make a contrast of the rise and the fall of the voice in speaking. Sometimes, the rise and fall of the voice in speaking just makes the speech more pleasing to the ear, but sometimes changes the meaning of the speaking. Once the students get to know this, they will not neglect the intonation any more. The following step for the teacher is to find some audio and video materials for the students to imitate. Imitation is a good way for a second language learner to improve spoken English, especially for intonation. At the beginning of the imitation, the materials should be received standard [3]. The teacher can hold a very short contest of intonation imitation in class. The students may be divided in groups if it is a class with large numbers. The contest of intonation with repetitious practice impress on the students the importance of the rise and fall of the voice.

\section{B. After-class Guidance}

Some of the Chinese students are shy and afraid of making mistakes in speaking. That is, they lose chances to speak in and after class. Therefore, the teacher should help the students set up their self-confidence and at the same time enhance their interests in speaking English. The Teacher should try their best to make the students believe that they can express themselves freely in English just like the native speakers by great efforts. Cook has ever said that people learn speaking by listening [4]. It is just by listening and communicating with others can we help students to improve their competence in oral expression. The teacher can stimulate the students to read a lot and listen to the 
materials of all kinds of topics because it is common for us to come across various kinds of topics in daily conversations. The background information helps students have open minds, which unconsciously support them in their oral expression.

Besides, the teacher should advise students to attend the optional classes related to English, stimulate them to take part in English corners and talk with English foreign teachers boldly, cultivate their interests in oral English expression and communicating as much as possible with English-lovers and English-learners. After class, students become active learners. They can choose any thing they like to learn and the ways to learn it. Many colleges have bilingual classes, such as martial arts class in English, which has aroused great interests and attention for college students. The students also can be encouraged to join in the online voice chat in English. Students can be advised to study courseware at the back of the textbook by reading after the courseware to learn authentic pronunciation and describing the pictures in English to enhance the descriptive and narrative ability. Besides, there are some language-learning drills which makes students quick-witted in the speech, such as singing English songs and practicing tongue twisters.

A foreign language should be learned by using it [5]. School and social activities provide opportunities for the second language learners to improve their oral competence. For group activities on campus, various kinds of oral contests, speeches, public debates and regular English corners are all good ways to improve oral English competence. In society, there are also some chances to practice spoken English. A student can express their academic points and communicate with other scholars and teachers in some international conferences. They also can be an volunteer English guide in a historic site or are involved in voluntary service in any international activities. In a word, the time is always limited in class, while the enormous days outside class should be utilized fully for college students.

\section{CONCLUSION}

College students have some problems in spoken English, but if we find out the specialties and the essence of these problems, it will be easier for teachers and students to solve the problems together. The experiences will benefit a lot of students in China. For a second language teacher, the allimportant condition of foreign language teaching seems to encourage students to make contact with this language as much possible as they can and use it but not get a sprinkling of water now and then. The Danish linguist Jespersen tells the direction of English teaching. Oral English teaching should be the emphasis in college English teaching. Until students are ducked down in water, can they become able swimmers, surfing in the water freely and enjoyably.

\section{REFERENCES}

[1] Bax,S. The End of CLT:a Context Approach to Language Teaching. ELT Journal, 2003, 57 (3), pp. 278-287.

[2] Watkins, D. A.,Biggs,J. B.,Watkins,D. A.,Biggs,J. B. The paradox of the Chinese learner and beyond. Teaching the Chinese learner: Psychological and pedagogical perspectives. Hong Kong, PRC/Melbourne, Australia: CERC/ACER, 2001, pp.3 23.

[3] Kaplan,R.B, Baldauf, R.B.Jr. Language and Language-in-Education Planning in the Pacific Basin.Dordrecht,Nether-lands: Kluwer Academic Publishers, 2003, pp.23-24.

[4] Cook. V. Second Language Learning and Language Teaching[M] Beijing: Foreign Language Teaching and Research Press, 1996.

[5] Jespersen, O. How to Teach a Foreign Language. .London: Allen \& Unwin, 1904 